\title{
THE UNIFORM LAW ON INTERNATIONAL SALE OF GOODS: A CONSTRUCTIVE CRITIQUE
}

\author{
Harold J. Berman*
}

\section{INTRODUCTION}

In no other major branch of law is there more uniformity among the principal legal systems of the world than in the law of international sales. Contract law relating to documentary transactions, the law of carriage of goods by sea, rail, and air, the law of marine insurance, and the law of bank credits and acceptances, are basically the same in their general character-so far as international sales are concerned-in the so-called "common law" and "civil law" systems as well as in the legal systems of the centrally planned economies of the Soviet Union, Eastern Europe, and China.

The reasons for this are not hard to find. On the one hand, the merchants, carriers, underwriters, and bankers of the world who engage in international sales transactions have had centuries of experience in establishing common practices and common norms. Moreover, they continually renew their common traditions through negotiation of contracts, through arbitration of disputes, and through the establishment of rules by trade associations. On the other hand, lawyers and lawmakers of many countries have also responded, over the centuries, to the need for uniformity in the law of international sales, and have helped to develop such universal legal institutions as the c.i.f. contract, the bill of lading, the marine insurance policy and certificate, the bill of exchange and letter of credit.

Commercial codes of France, Germany, Italy, the Scandinavian countries, the United States, and other countries, and general commercial statutes like the British Sale of Goods Act, are themselves based partly upon the international "law merchant," and national courts have received international commercial law through the application of such codes and statutes as well as through interpretation of international sales contracts. Uniformity has also been bolstered by international conventions such as the Brussels Convention on Carriage of Goods by Sea and others, as well as by rules adopted at international conferences, such as the 1932 WarsawOxford Rules for CIF Contracts, and by comprehensive contract conditions worked out for various types of exports by the United Nations Economic Commission for Europe. Finally, state trading agencies of all countries, including countries of centrally planned economy, have to a large extent adapted themselves to traditional international commercial-law institutions; indeed, even in trade with each other, the countries of centrally planned economy employ contract techniques and contract

- Professor of Law, Harvard University. The author is grateful to Joseph L. Gibson, LL.B., Harvard University, 1965, for valuable assistance in the preparation of this article. 
law that closely resemble-in their main outlines-the techniques and law of international trade in Western Europe, England, and the Americas.

Nevertheless, despite the high degree of universality of basic concepts in the law of international trade, there remain many differences in their detailed application; and this multiplicity of minor differences often presents serious obstacles both to the negotiation of international sales contracts and to the resolution of conflicts arising out of such contracts. Indeed, even slight differences in the wording of similar rules may give rise to difficulties in reaching agreement in advance and in settling disputes thereafter. In addition, minor differences in the general contract law of different countries regarding such matters as formation of contracts, breach, damages, and the like, sometimes lead to substantially diverse results in similar cases. The need, therefore, for further unification of the law of international sales continues to be a pressing one.

\section{The Significance of "Minor" Differences}

These elementary truths are the necessary foundation for an evaluation of the x 964 Hague Convention relating to a Uniform Law on the International Sale of Goods (hereinafter referred to as the ULIS). It must be understood, first, that the need for such a convention arises not primarily from the existence of major conceptual differences among legal systems (for such major conceptual differences in this area of the law are few in number), but rather from the existence of a great many minor differences; and second, that any resolution of the minor differences must preserve and clarify the common practices and norms that have been developed-and are continually being developed-by the international trading community, and that are reflected (not always uniformly) in national legal systems.

The framers of the ULIS have, unfortunately, taken a different approach. They have sought to eliminate from the law of international sales the application of national law, including the large body of international commercial law and custom contained in national law, and to substitute, as a self-sufficient code, a relatively few general rules. ${ }^{2}$ These rules are conceived as a subsidiary law, to be applied by national courts and arbitral tribunals in the light of particular contracts and in

${ }^{2}$ CF. Berman, The Unification of Contract Clauses in Trade Between Member Countries of the Council for Mutual Economic Aid, 7 INT'L \& CoMP. L.Q. 659 (1958), containing a translation of the standard contract conditions adopted by the CMEA in 1958 .

${ }^{2}$ ULIS art. 2, discussed infra, excludes the application of rules of private international law unless the contract provides otherwise. CF. Rabel, The Hague Conference on the Unification of Sales Law, I Ax. J. Comp. L. 58, 60 (I952): "Within its corners, however, the text must be self-sufficient. Where a case is not expressly covered the text is not to be supplemented by the national laws-which would at once destroy unity-but to be construed according to the principles consonant with its spirit."

The exclusion of private international law is convincingly criticized from the point of view of conflict of laws by Nadelmann, The Uniform Law on the International Sale of Goods: $A$ Conflict of Laws Imbroglio, 74 YALE L.J. 449 (1965). The present article approaches the question from the point of view primarily of the law of sales. Cf. Nadelmann, at $46 \mathrm{r}$. 
the light of usage. ${ }^{3}$ The pressing practical problems of a more specific character are, for the most part, ignored. A businessman or lawyer who studies the ULIS for answers to the questions that cause special difficulty in the drafting of international sales contracts, or a court that looks to it for guidance in resolving disputed issues of interpretation of such contracts, or of interpretation of law or usage, will bc disappointed.

It would be ungrateful to the many distinguished European jurists who have worked for decades to produce the ULIS not to recognize that what it sets out to do, it does very well. It succeeds admirably in harmonizing, in a generally acceptable way, basic principles of the law of international sales reflected in various legal systems. Rules concerning obligations of seller and buyer, breach, damages, excuse, the passing of the risk, and a variety of similar matters, are presented clearly and intelligently. Although one may quarrel with many of the formulations, especially in English translation, ${ }^{4}$ most of the provisions of the ULIS relating to the obligations of seller and buyer could be adopted by most of the major trading nations of the world without too much difficulty-and indeed, without substantially changing their existing law. By the same token, however, the ULIS does not eliminate those national diversities that are most oppressive to international trade, for those diversities, as we have said, are diversities not of basic principle but of specific application.

A few examples may help to make this clear:

(a) There is considerable diversity among different legal systems concerning the documents to be tendered by the seller in order to satisfy the requirements of a c.i.f, contract, absent an express contractual indication. May a delivery order be tendered instead of a bill of lading? ${ }^{5}$ May a marine insurance certificate be tendered

- ULIS art. 3, discussed infra, permits the parties to exclude the ULIS in whole or in part. Article 9 provides that the parties, unless they otherwise agree, "shall be bound by usage which reasonable persons in the same situation as the partics usually consider to be applicable to their contract." But unfortunately, the word "usage"-whose meaning is by no means uniform throughout the world-is itself not defined in the ULIS.

The English translation contains some terms that are not familiar to English and American lawyers and some familiar terms that mean something different in the French original. Also there are some plain translation errors. The most serious translation problem is the rendering of the French deliverance, which means something other than "delivery" as understood in England and America; this is discussed below. An example of awkwardness may be found in section II (article 74), which is entitled Exoneration in French and "Exemptions" in English; a better translation would be "Excuse." The last phrase of article $74(x)$ is improperly translated: ". . . regard shall be had to what reasonable persons in the same situation would have intended"-instead of ". . . regard shall be had to what reasonable persons in the same situation normally intend." The correct translation suggests a more objective test. There are many other examples of linguistic difficulties that suggest that the English version requires a rather thorough revision.

${ }^{5}$ In a case decided by the House of Lords involving an Argentine seller and a Belgian buyer, a contract labelled "c.i.f." expressly permitted the seller to tender to the buyer a delivery order covering a portion of a shipment of rye sold afloat. The House of Lords held that the delivery order had no commercial value and that the use of it, instead of a bill of lading, transformed the contract into a destination contract. Comptoir d'Achat et de Vente du Boerenbond Belge, S.A. v. Luis de Ridder, Limitada (The Julia), [1949] I All E.R. 269 (H.L.). The decision seemed to meet with the approval of Belgian jurists. Cf. de Juglart \& Chasseriaux, Le delivery order. Ses diverses formes, 3 Revuz Trimestrielur de Droit Commerciat 124 (I950), Jacques van Doosselaere, Observations, 93 Jurisprudence du Porr D'Anvers 316 (1949). It is at least possible, however, that a different result would be reached in the 
instead of a policy? ${ }^{6}$ Does the duty to provide insurance include the duty to provide war risk insurance?t The ULIS simply avoids such questions. It does not mention bills of lading, marine insurance certificates or policies, or other particular types of documents, and it does not meniton c.i.f. contracts.

(b) There is also considerable diversity among different legal systems concerning the effect of the denial or revocation of an export (or an import) license by the government of the exporter (or importer) upon the seller's and buyer's obligations. Absent an express reference in the contract, which party is to bear the risk of such a contingency? ${ }^{8}$ The ULIS contains an excellent general definition of excuse for nonperformance (article 74)-one which can probably be harmonized with existing doctrines of impossibility or frustration in most countries-but it does not say anything about denial or revocation of export or import licenses or about governmental intervention of any other kind or, indeed, about any specific types of contingencies that will or will not excuse unless the parties expressly provide otherwise.

(c) The ULIS expressly provides for the seller's right of stoppage in transit only in the event that the economic situation of the buyer has become difficult (article 73). Probably the right of stoppage may be considered to exist, as a matter of international trade usage, in other circumstances as well (e.g., in case of the buyer's breach not caused by economic difficulties). Nevertheless, usage concerning the scope of the right of stoppage in transit is by no means clear. For example, when goods are transshipped difficult questions may arise concerning whether a carrier or warehouse is the agent of the seller or of the buyer, and whether, therefore, the goods remain in transit or have, from the seller's point of view, come to rest. ${ }^{9}$ Also it is not certain what rights and duties the bailee may have, when confronted with an order to stop in transit-whether, for example, he must obey a notification to stop or may insist on surrender of a negotiable document of title, and whose notification he must obey in the event that the goods are shipped by a straight bill. ${ }^{10}$

The ULIS contains almost nothing on agency or on rights of bona fide purchasers or of bailees; these subjects have been excluded on the ground that the ULIS should

United States under the Uniform Commercial Code, which includes delivery orders among documents of title. Cf. UCC r-zor.

${ }^{\circ}$ English and American courts are divided on this question. Cf. Diamond Alkali Export Corporation v. Fl. Bourgeois, [192I] 3 K.B. 443, and Kunglig Jarnvagsstyrelsen v. Dexter \& Carpenter, Inc., 299 Fed. 99 I (S.D.N.Y. 1924).

7 The Uniform Commercial Code provides that the c.i.f. seller must take out customary war risk insurance for the benefit of the buyer. This is said to have changed the common law on this point. UCC $2-320(2)(c)$, and comment 7 .

${ }^{8} \mathrm{Cf}$. Berman, Excuse for Nonperformance in the Light of Contract Practices in International Trade, 63 Colum. L. REv. I413, I436 n.49 (1963); id., Force Majeure and the Denial of an Export License under Soviet Law, 73 HARv. I. Rev. I 128 ( 1960$)$, and authorities there cited.

- Under American law, generally speaking, the seller may stop shipment if the bailee holds the goods for the benefit of the seller but not if he holds them for the benefit of the buyer. Conflicting judicial decisions were resolved in the Uniform Commercial Code by the provision that the right of stoppage ceases to exist if a bailee (including a warehouseman) acknowledges to the buyer that the goods are held for him or if a negotiable document of title is transferred to the buyer. UCC $2-705(2)$.

${ }^{10} \mathrm{CF}$. UCC $2-705(3)$. 
deal only with buyer and seller and not with third parties. But even assuming that this were sound as a general matter, it is surely unsound when the rights of seller and buyer vis-à-vis each other depend entirely on their rights vis-à-vis third parties-as in the case of stoppages in transit, and, indeed, in a great many other even more important cases.

A great many of the gaps that exist in the ULIS, though by no means all of them, derive from the decisions of its authors to exclude from consideration the various types of documentary sales. Two articles ( 50 and $5 \mathrm{x}$ ) are devoted to documents, but they say almost nothing except that where documents are called for they must be tendered. Documents are also referred to in various other articles, but nowhere is there any definition of them and and nowhere is there any reference to the obligations of seller and buyer in c.i.f., f.o.b., and other types of documentary sales. These subjects were considered to be too complex to be covered in a Uniform Law on International Sale of Goods. ${ }^{11}$ The result is a law that is too simple to be helpful, for the typical international sale of goods is the documentary sale, and from the documentary sale stems a very large part of international sales law.

Even apart from the omission of documentary sales, the ULIS for the most part does not attempt to answer specific questions of the application of its general rules. It does not, for the most part, define its terms. It does not, for the most part, attempt to state the qualifications and exceptions to its rules. These are not, of course, oversights, but matters of conscious policy concerning the technique of the law. One of the principal supporters of the ULIS, André Tunc, has justified its technique as being in the Continental style of legislation and has asked that "Anglo-American" jurists accept it as such. ${ }^{12}$ One might quarrel with this on theoretical grounds: the ULIS may be in the style of the French Code civil, but it is hardly in the style of the German Handelsgesetzbuch or, indeed, of the French Code de commerce. ${ }^{13}$ It does not reflect the concern for specificity and certainty that is characteristic of commercial legislation, as distinct from the general law of contracts, in Europe as well as else-

11 The r95I Rome Draft of the ULIS contained some provisions on c.i.f., f.o.b., and other types of so-called "maritime" sales (in fact they are used quite commonly in international trade for ovcrland as well as overseas transactions). These were omitted from the 1956 and 1964 versions as being "inadequate to regulate a subject matter as complex as the great maritime sales." Report of the Commission, Specint Commission Appointed by the Hague Conference on the Sale of Goods 33 (The Hague, 1963).

${ }_{12}$ Tunc, Les Conventions de la Haye du 1er juillet 1964 Portant Loi Uniforme sur la Vente Inter. nationale d'Objets Mobiliers Corporels, i6 Revue Internationaze de Droit ComparE 547, 554 (Iy64): "Il est simplement permis de penser que les pratiques commerciales de l'Europe, ses conceptions ct ses institutions juridiques, son style législatif meme, ont aussi leur valeur, et que ce serait une perte pour unc loi uniforme de portée plus universelle que celle de $\mathrm{La}$ Haye de négliger ces pratiques, ces conceptions et ce style...."

13 The 1964 edition of the Handelsgesetzbuch, including supplementary legislation, runs to 1005 pages of small print, plus appendices and index. In addition to the law of maritime trade and carriage of goods, it also covers bills of exchange, company law and rules of competition. The $x 959$ Dalloz edition of the Code de Commerce, with supplementary legislation and annotations, runs to 883 pages of even smaller print. It also covers most aspects of business law. Both of these codes combine general rules with detailed qualifications and exceptions; both are intended not only to guide courts in the resolution of disputes but also to guide merchants in making specific, detailed contractual arrangements. 
where. Moreover, even if it were in the "civil law" tradition, as against the "common law" tradition, that surely would be a matter of some concern, since the United States alone conducts more than one-seventh, and together with the United Kingdom, Canada, Australia, and New Zealand more than one-fourth, of the world's trade. Would it not therefore be preferable to combine the two legal traditions-especially in the field of international trade, where both have already yielded much to the transcending pressures of international practices and norms?

But the rivalry of legal traditions is a trivial matter compared to the basic question of whether a codification of more or less universally accepted general principles, such as are contained in the ULIS, will (a) aid merchants who are engaged in international trade to reach agreements, and (b) aid in the uniform settlement of disputes arising out of such agreements-either by the parties themselves or by courts and arbitral tribunals.

\section{II}

\section{The Autonomy of the Parties}

Assuming that the ULIS is too general to be very helpful, is it harmful? To answer that question we must consider (I) the power of the parties to a contract to exclude the application of the ULIS, (2) their power to supplement its general rules by specific contractual clauses, and (3) the power of the courts to supplement the ULIS by drawing upon other sources of law.

\section{A. Choice of Law by the Parties}

Article 2 of the ULIS excludes the application of rules of private international law except in a few special instances. ${ }^{14}$ Thus with minor exceptions, an international contract of sale is to be governed by no law except the ror articles of the ULIS, plus the terms of the contract itself. However, article 3 provides that the contract may, if the parties so choose, exclude the ULIS "either entirely or partially," and that "such exclusion may be express or implied." Thus the parties may write their own conflicts rules, or may choose an applicable law, or may exclude particular provisions of the ULIS. Unless, however, they do so expressly, difficult questions will undoubtedly arise concerning whether or not they intended the ULIS, or a particular article or articles thereof, to be applicable. The generality of the provisions of the ULIS will make it almost impossible to know whether a contractual clause that contradicts an article of the ULIS in some particular respect is meant to exclude the article entirely or only to make a single exception to it.

It should also be stressed that in many circumstances it will be very difficult, as a

16 Article 16 leaves the question of entering or enforcing a judgment of specific performance open to determination by national law. Article 38 states that methods of examination (inspection) of goods shall be governed, in the absence of agreement of the parties, by the law or usage of the place where the examination is to be effected. Article 89 states that in case of fraud, "damages shall be determined by rules applicable in respect of contracts of sale not governed by the present Law." 
practical matter, for a party to exclude the ULIS, whether in whole or in part and whether by express provision or by implication. If either the exporter or the importer is benefited by the ULIS, he will resist the choice of another law or of a contradictory contract clause, and he will have behind him the prestige of an international convention. Even without the ULIS it is often very difficult for parties to international sales contracts to agree on an applicable law, or, indeed, on a departure from a standard legal norm even though it is dispositive rather than mandatory. In many places in the world it is considered a matter of national pride not to accept the application of a foreign law, especially when the party that is asked to accept it is a state agency. And it sometimes happens that while the lawyers for the exporter and the importer are struggling over the question of a choice-of-law clause, their principals, being in haste and not anticipating difficulties, will sign the contract.

\section{B. Ad Hoc Contractual Rules}

Since, however, the purpose of the ULIS is to be applied, not excluded, the more pertinent question is whether its excessive generality may be redeemed by specific contractual provisions viewed in the context of international trade usage. This is, in fact, the major premise upon which the technique of the ULIS is based-that the detailed obligations of the parties can be, and should be, regulated by the contract itself, interpreted in the light of usage, with legal rules playing a "subsidiary" role.

One suspects that this premise derives from the study of contracts after they have been drafted rather than from the experience of negotiating and drafting them. It is a matter of common commercial experience that international sales contracts are generally drafted against a body of law, and that the less specific the law, the more detailed the contract must be. A New York exporter of textiles, for example, may use a contract containing only a half-dozen "general conditions," so long as one of those conditions is that the contract shall be governed by New York law. That is because the Uniform Commercial Code, adopted in New York, taken together with New York judicial decisions, contains the answers to most of the specific questions about which the exporter is concerned. If, on the other hand, the law of his French buyer is to be applicable, the exporter would want to retain the services of a lawyer who knows the answers given by French law to the specific questions about which he is concerned, and he would want to draft the contract in the light of those answers. If the exporter and importer cannot agree on a choice-of-law clause, they would normally assume that either New York law or French law would probably be applicable, under the general rules of private international law, and would negotiate the terms with that in mind.

If, however, neither New York law nor French law is applicable, but instead the contract is to be governed solely by the ror articles of the ULIS and by usage, the parties would need to insert into their contract specific clauses restating, in effect, 
those rules of the law of international trade that are not contained in the ULIS and are not clearly defined by usage. They could not, without considerable uncertainty, simply use the terms "c.i.f." "marine insurance certificate," or other standard trade terms, without defining them; they could, of course, incorporate by reference definitions developed by trade associations (especially, the American Foreign Trade Definitions and the Incoterms of the International Chamber of Commerce), but these by no means answer all questions. The parties would also need to include their own rules on assignment of contract rights, insurable interest, rights of bona fide purchasers, and a host of other critical matters entirely omitted from the ULIS. Presumably such matters are to be governed by national law, but they are so closely related to the matters governed by the ULIS that often it would be very difficult indeed to separate the two.

Even with respect to matters not omitted but covered by general rules in the ULIS, the parties would want to specify in their contracts many of the detailed applications of those rules. This alone would require a very great expansion of the simple contract forms now used in many trades. It would be desirable to include in every contract all sorts of provisions now dealt with (though not uniformly) by national laws-for example, that the buyer's expenses of inspection must be reimbursed by the seller in the event that the goods prove to be nonconforming; ${ }^{15}$ that the ULIS requirements of notification in various articles are satisfied if notice is dispatched (or alternatively, only if notice is received) $;^{16}$ that where the seller manufactures goods to the buyer's specifications the buyer shall indemnify the seller against any losses due to patent infringements; ${ }^{17}$ that the buyer's obligation to pay is discharged if payment is made in a currency other than that provided in the contract where such alternative payment is required by a governmental regulation unless such regulation is discriminatory or oppressive $;^{18}$ and dozens of other clauses of like scope. Matters of expenses of inspection, notice, damages, payment, and so on, are, to be sure, dealt with generally in the ULIS, but not in the detailed manner in which they are covered in national legislation and judicial decisions, and therefore not in a manner to satisfy the overriding need for certainty in sales transactions between citizens of different countries.

At the very least, then, the adoption of the ULIS would require a very great readjustment in the contract practices of many enterprises engaged in international trade. In many trade associations one might expect to see the emergence of long form-contracts, with scores of clauses, along the lines of the General Conditions worked out for various trades by the Economic Commission for Europe; the ECE contracts, too, like the ULIS, were premised on the effort to exclude the application

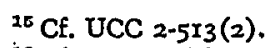

10 Cf. ULIS articles I9, 30, 43, and others, which require parties to "send notice," "declare," "inform," but do not indicate the consequences of failure to receive the message.

${ }^{27}$ Cf. UCC $2-312(3)$ and comment 3.

${ }^{18}$ Cf. UCC $2-6 \mathrm{r}_{4}(2)$. 
of rules of private international law. Without the auspices of an international agency of the United Nations, such detailed form-contracts could become very oppressive; and trade associations themselves would be strongly opposed to the abandonment of the short contracts that now predominate in many types of trade and that are easily understood by merchants.

Where, however, exporters and importers do not use form-contracts developed by trade associations-and such use is much less common in the United States than in Europe-the difficulties would be even greater, for their foreign customers would be reluctant to accept a set of General Conditions that looked like a restatement of the Uniform Commercial Code or the German Hondelsgesetzbuch. In addition, many exporters and importers would be reluctant to incur the legal expenses that would necessarily be involved in drafting and negotiating such contracts.

\section{Standards for Adjudication and Arbitration}

Even if the parties could succeed in agreeing upon contract clauses that cover the main questions of international sales law that are neither included in the ULIS nor clearly defined by usage, their troubles would not be over. For if a dispute should arise concerning the interpretation of the agreed-upon clauses they-or a court or arbitral tribunal-would face the problem of finding a basis for such interpretation outside of any existing national legal system.

In an effort to meet this problem, article I7 of the ULIS provides: "Questions concerning matters governed by the present Law which are not expressly settled by it shall be governed in conformity with the general principles on which the present Law is based." Since no "general principles on which the present Law is based" are stated, one may only guess that article $I 7$ is an injunction to observe the spirit of reasonableness and good faith that pervades the ULIS as a whole. However, reasonableness and good faith are often an inadequate guide to the resolution of close questions of interpretation, especially in disputes between citizens of different countries. Moreover, article I7 seems to forbid a court to look to its own or any other national law in construing contract clauses that fall outside the express language of the ULIS and are not clearly defined by usage, provided that they concern matters that are governed by the ULIS, albeit in the most general terms. However, neither this nor any other proposition concerning the meaning of article 17 can be asserted with conviction.

Thus, if the parties were to include in their contract any or all the provisions on sales law that are now contained in the Uniform Commercial Code-for example, concerning matters that are only very generally treated in the ULIS, and on which usage is unclear or not uniform-there would still be missing the American case-law and legal commentaries that interpret those provisions. Yet contracts of such complexity could scarcely be understood if taken out of the context of an articulated 
legal system. The same would be true, of course, if rules of German or French statutory and decisional law were written into the contract and a court or arbitral tribunal were required to interpret such rules without reference to German or French law as a whole.

\section{III}

\section{The Arrocation of Risks}

Perhaps the weakest part of the ULIS, next to its exclusion of the rules of private international law, is its section on "risk." This section, placed at the end of the text, contains only six articles, each very general in character:

(x) Article 96 states that where the risk has passed to the buyer he shall pay the price notwithstanding the loss or deterioration of the goods.

(2) Article 97 states that the risk shall pass to the buyer upon delivery of the goods. (Under article I9, handing over conforming goods to the carrier for transmission to the buyer constitutes delivery when no other place of delivery has been agreed upon.)

(3) Article 98 deals with the passage of the risk when delivery is postponed owing to the breach of an obligation of the buyer.

(4) Article 99 states that where there is a sale of goods afloat, the risk shall be borne by the buyer as from the time they are handed over to the carrier, unless the seller, at the time of the conclusion of the contract, knew or ought to have known that they had been lost or had deteriorated.

(5) Article roo states that in the case of goods that were not appropriated to the contract when handed over to the carrier, the risk remains with the seller until notice of the consignment is sent to the buyer, if the seller knew or ought to have known that the goods had been lost or had deteriorated after they were handed to the carrier.

(6) Article Ior states: "The passing of the risk is not necessarily determined by the provisions of the contract concerning expenses."

Commercial lawyers will rejoice that the ULIS does not make the obligation to pay the price depend upon the transfer of property in the goods. In this the ULIS reflects the modern statutory law or judicial practice of most countries. The modern view, which separates passage of risk from passage of title, is a reaction against what Karl Llewellyn used to call "lump-concept thinking," as well as against the particular "lump-concept" of property. No single idea or formula can resolve the very complex and diverse kinds of transactions that make up international sales. Especially the elusive concept of "property," with its different significance for creditors, taxing authorities, insurance companies, bailees, financing agencies, as well as buyers and sellers, and with its different interpretations in different countries, must 
yield to more specific and more realistic tests of commercial understanding with respect to risks of loss or damage.

By the same token, however, one must beware of attaching too much affection to the lump-concepts of "delivery" and "risk." There are deliveries and deliveries; and there are risks and risks. This does not mean that doctrines cannot be developed to encompass the variations; it only means that the doctrines must indeed encompass them, and not force them into a single mold.

John Honnold has carefully analyzed the concept of delivery (delivrance) as developed in the ULIS, and has shown how it differs from the concept of "handing over the goods"-and hence from the American concept of delivery. ${ }^{10}$ If the ULIS is ratified by a sufficient number of states, American international lawyers and traders will have to grasp the elements of the subtle concept of delivrance, with its mixture of fact and law. In the opinion of the writer, it is a concept that has much to commend it; in any event, it is one of the few basic terms that are defined in the ULIS and its various connotations are made clear from the various contexts in which it is used.

The concept of "risk," on the other hand, is not defined. Judging from article 96 , it refers only to the buyer's obligation to pay the price notwithstanding the loss or deterioration of the goods. It is apparently the German Preisgefahr, or "price-risk," although in French it it used in the plural (les risques). However, the word "risk" in "price-risk," at least as used in the ULIS, does not seem to have the meaning of "danger" (Gefahr) but only the meaning of obligation. Indeed, the word "risk" could apparently be eliminated from the ULIS without affecting the meaning of the law: instead of saying that the risk passes upon delivery (article 97) and that when the risk passes the buyer shall pay the price (article 96), one could simply say that upon delivery the buyer shall pay the price. Similarly in other articles of the ULIS that refer to "the time when the risk passes" (e.g., article 35), the phrase "the time of delivery" could be substituted.

In short, the factual content of the term "risk" as used in other contexts outside the ULIS-e.g., the risk that the carrier will misdeliver the goods, the risk that the goods are not adequately insured, the risk that they will be diverted by act of a government, and so on-is missing. Perhaps some such factual content is implied in the qualification attached to the price-obligation: "notwithstanding the loss or deterioration of the goods." This seems to make "risk" in the ULIS comparable to "risk of loss or damage." On the other hand, it is uncertain, under article 96 , that the buyer must assume all risks or loss or damage; he might be obligated to pay the price and nevertheless retain a right of action against the seller for damage to the goods.

Apart from ambiguities arising from the failure to define risk, there are additional ${ }^{10}$ Honnold, A Uniform Law for International Sales, I07 U. PA. L. REv. 209, 317 et seq. (1958). 
difficulties in the proposition that risk follows delivery (delivrance) and priceobligation follows risk. Three examples may help to illustrate these difficulties. All three involve, on their face, "shipment" contracts, in which the seller agrees to deliver goods by handing them over to a carrier for transmission to the buyer, and the buyer agrees to pay the price upon delivery notwithstanding the loss or deterioration of the goods. In the first example, the seller (a manufacturer-exporter) is excused from liability for nonperformance because of the accidental destruction of the manufactured goods prior to delivery, but the buyer is nevertheless required by the contract to pay the price. ${ }^{20}$ In the second example, the contract provides that the seller (a broker-exporter) will be responsible for the deterioration (e.g., shrinkage) of the goods after delivery-in other words, that the buyer may deduct from the price the loss in value due to the deterioration in transit. ${ }^{21}$ In the third example, the buyer is not liable for the price at all-even though conforming goods were delivered by being handed over to the carrier for transmission to him-because the seller transferred to him (as provided in the contract) a delivery order, not signed by the carrier, instead of a bill of lading. ${ }^{22}$

From the point of view of the ULIS, these examples, all of which are not uncommon, simply represent contractual deviations from the "dispositive" provisions of articles 96-Ior, i.e., provisions that are effective only if the parties do not stipulate to the contrary. The ULIS does not say that the buyer may not ever be liable to pay the price prior to delivery, or that the seller may not ever be liable for deterioration of the goods after delivery, or that the buyer may not ever be excused from liability to pay the price after delivery. It only insists that these deviations from the norm must be provided for by contract. Unfortunately, however, the problem is not so easily resolved. Not only do difficulties arise in drafting appropriate clauses varying the risks, in view of the absence of specific legal definitions and standards, but also such clauses cast doubt upon the price-obligation itself.

If, for example, clauses are inserted in the contract guaranteeing the weight of the goods on arrival, or providing that freight is payable only on arrival, or that the buyer shall have the right to inspect the goods after arrival, or that the duty to insure is the buyer's responsibility, or that the seller will tender a delivery order rather than a bill of lading-then the contract may or may not be turned from a shipment contract into a destination contract, and the buyer may or may not be obligated to pay the price in the event that the goods are lost. The ULIS only deals with this matter in a single phrase: delivery is effected by handing over the goods

\footnotetext{
${ }^{10}$ CE. U.S. Steel Export Company, General Conditions of Sale-C.I.F. and C.\&F. Sales (rev. Dec. I, 1949).

II The phrase "net landed weights" is often used by traders to place some risks of deterioration of the goods in transit upon the seller while shifting other risks to the buyer. Sometimes courts have interpreted this and similar phrases as transforming the contract from a shipment to a destination contract. The Uniform Commercial Code regulates the matter in section 2-32x.

${ }^{28}$ CE. The Julia, supra note 5.
} 
to the carrier "when no other place for delivery has been agreed upon" (article Ig). But nothing is said about how to determine whether another place for delivery has been agreed upon, i.e., whether the contract is a destination contract. In fact that question can only be answered by analyzing how the parties have allocated the various risks.

Thus the ULIS concept of risk is circular: risk passes upon delivery (in the ULIS sense of handing over conforming goods for transmission to the buyer), but delivery turns-partly, at least-on passage of risk. It surely turns on the parties' allocation of the risks of loss or deterioration of the goods; more realistically, it should also turn on their allocation of other risks, such as transportation, insurance, credit, and government intervention.

The only reference in the ULIS to the effect of contractual clauses on the passing of risk is in article ror, which states: "The passing of the risk is not necessarily determined by the provisions of the contract concerning expenses." This says nothing. The passing of the risk should not necessarily be determined by any single provision of the contract.

Because the concept of risk in the ULIS appears to be merely a formal link between delivery (delivrance) and the price-obligation, the law is left in a state of confusion that may in many cases resist even the most careful drafting of contracts. ${ }^{23}$

\section{IV}

\section{The LaCK of Specificity}

It is, above all, the lack of specificity of the ULIS that will impose heavy burdens on drafters of international sales contracts and on courts and arbitral tribunals called on to interpret such contracts. The failure to define more than a few of the basic concepts of the ULIS and to state more fully the qualifications and exceptions to its general rules; the failure to deal with so-called trade terms (c.i.f., f.o.b., and so on) and with the special problems of sales performed by delivery of transportation, insurance and banking documents; and the failure to relate delivery (delivrance) to risk in a more meaningful way, by spelling out the effect of various contractual allocations of risks upon the time and place of delivery (and hence upon the buyer's obligation to pay the price)-all of these seem to this writer, at least, to be substantial defects, even apart from the exclusion of rules of private international law that might help to remedy them.

But these are all defects that can be overcome. It is not necessary to tear down the basic foundation and design of the ULIS in order to supply its missing super-

${ }^{28}$ Professor Honnold wrote of the 1956 draft of the ULIS: "Risk of loss presents the draftsmen of the Uniform Law with their most significant and challenging opportunity for improvement." Honnold, supra note 19, at 316. Unfortunately, the draftsmen did not seize the opportunity, but left the earlier provisions on risk virtually unchanged. 
structure. Its reliance on international trade usage and on contract practices as the ultimate source of international sales law is sound. Its harmonization of basic concepts of international sales law is valuable. What is needed is, first, a recognition that just as the ULIS is subsidiary to usage and contract, so national law-applicable under the rules of private international law-must be retained as subsidiary to the ULIS; and second, an elaboration of the ULIS to include a great many more rules dealing with those specific problems of international sales law that are not treated uniformly by national laws or by usage. ${ }^{24}$

The elimination of article 2, with its exclusion of private international law, would solve a great many-though by no means all-of the problems that arise from the excessive generality of the ULIS. National law would then be subsidiary to the ULIS, filling in its gaps. It is true that many new problems would arise concerning the relation between the provisions of the ULIS and those of the national law. ${ }^{25}$ Such problems would become especially acute when there is a clash of basic concepts between the ULIS and the national law. It seems to this writer, however, that the basic concepts of the ULIS are sufficiently universal to permit a satisfactory adjustment-ultimately, at least-between it and national legal systems viewed as subsidiary to it.

Assuming that the ULIS is amended to permit rules of private international law to be applied without special contractual provisions therefor, the need for amplification, definition, and qualification of its general rules will nevertheless remain acute. Without more specificity, there will be very great uncertainty as to whether or not there is a gap in the ULIS requiring the application of the national law. This uncertainty, particularly in the area of documentary sales, will infect the drafting of contracts as well as the interpretation of them in cases of dispute. What is most needed, then, is to expand the ULIS to cover particular types of documentary sales, and to fill many of its present rules (especially those on risk) with more detailwithout, however, sacrificing the flexibility of its general concepts.

We have in the Sales Article of the Uniform Commercial Code one example of how sufficient detail can be achieved in the law of international sales while preserving the flexibility of general concepts. We do not suggest that provisions simply be extracted from the Uniform Commercial Code and inserted in the ULIS; that would only result in a hodge-podge. Moreover, the style and content of the Uniform Com-

\footnotetext{
24 Professor Honnold suggests that the reason the drafters of the ULIS did not deal with some of the important problems that may arise in sales transactions was "because of the peculiar difficulties anticipated in reaching international agreement." Honnold, supra note 19 , at $3 \mathrm{II}$. If this is so, it is a regrettable abdication. In fact, it might well prove easier to reach international agreement on specific matters of commercial importance-especially where the rules are subject to modification by the partiesthan on general matters of basic doctrine.

${ }^{25}$ The relationships between state and federal law in the United States provide an interesting parallel. Concepts of state law may be used to give the federal law meaning, where the federal law is in general terms, and in other cases the federal law may supplement state law. CE. Arthur T. von MeHREN * Donald T. Trauthan, The Law of Multistate Problems 1049-58 (I965).
} 
mercial Code may be too "American" to be acceptable elsewhere. Yet as Professor Clive Schmitthoff has said, "although the Uniform Commercial Code lacks elegance, it does answer the questions." It should be recalled that particularly in the Sales Article of the Code, the influence of the writings of Ernst Rabel was strong-and it was Rabel who gave leadership in the earlier drafts of the ULIS.

A revision of the ULIS by insertion of more specific provisions designed to reconcile conflicting rules of various legal systems will also challenge certain of its basic concepts. It will call in question the heavy emphasis on communication and cooperation between buyer and seller when difficulties arise-an emphasis that is more appropriate to intranational and intra-European trade than to long-distance overseas transactions. The inclusion of provisions on various types of documentary sales may also require some amendments of basic rules of the ULIS in order to distinguish obligations under contracts for the sale of plant and machinery from obligations under contracts for the sale of raw materials and agricultural commodities. The ULIS is intended to be law for the whole world, governing the most diverse kinds of sales, amounting in value to over $\mathrm{I} 35$ billion dollars a year, between enterprises that are often situated thousands of miles apart; of course, a high degree of generality is essential in such a law if it is to satisfy the need for uniformity, but at the same time, unless it is revised to make more elaborate distinctions between various types of transactions it may become a bed of Procrustes, with all kinds of international sales cut or stretched to a single size.

\section{Concrusion}

Codification of the law of international sales must, if it is to be successful, grow out of custom and belief-and, in particular, out of the common experience and shared concepts of the international trading community. This is recognized in the ULIS by the overriding effect given to what is there called "usage." Usage supersedes the ULIS itself, and contract, which also supersedes the ULIS, is to be interpreted in the light of usage. But in the commercial field, at least, legislation must not only reflect usage and refer to it, but must also develop and refine it. Otherwise legislation is not needed; and in law, surely, what is not necessary to do is necessary not to do.

We have entitled this essay a "constructive critique" because it is an effort to show how the ULIS can be, and should be, revised to develop and refine international trade usage. Since the time is not ripe to enact a comprehensive code embracing all aspects of such usage, opportunity to refer to the various national legal systems, which themselves incorporate international trade usage, must be provided. As there is a pressing need for a greater degree of uniformity and certainty, however, a new set of rules is needed-not only to restate basic concepts but also, and above all, to 
resolve those particular differences and uncertainties in national legal systems that are oppressive to international trade. Such an international codification must, of course, be a subsidiary law-as the ULIS is-in the sense that its rules should operate only when usage and contract are not decisive. But it must not sacrifice answers for elegance. It must tell both those who draft international sales contracts and those who enforce them what the rule is if the contract is silent or ambiguous. 